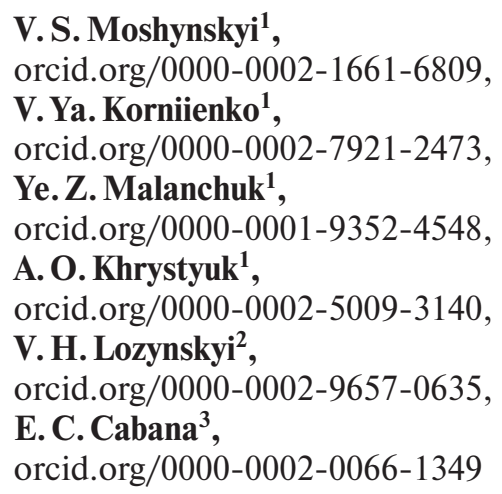

1 - National University of Water and Environmental Engineering, Rivne, Ukraine

2 - Geological Concern Geobit, Chrzanow, the Republic of Poland, e-mail:1vg.nmu@gmail.com

3 - Universidad Nacional de San Agustin de Arequipa, Arequipa, Peru

\title{
SIMULATION OF AMBER EXTRACTION PROCESSES FROM SANDY AND CLAY ROCKS WITH STOPE FILLING
}

Purpose. To develop a mathematical model for a system of amber extraction based upon physical cumulation and deflation effects under the conditions of turbulent flows.

Methodology. Theoretical simulation of the extraction processes took into consideration use of a basic aggregate, converting processes, compounding processes, modification processes, aggregating processes, processes of rotation series development involving practices of design and operation of the available similar facilities, design solutions, and widespread unification of both components and assembly units. Analysis of the gained theoretical and practical experiences helped simulate processes of amber extraction from sandy and clay rocks with stope filling.

Findings. Rock mass loosening by means of hydromonitor jets, operating tangentially in a casing while developing swirling pulp flows, has been simulated mathematically. A procedure to prepare filling material from mine tailing by means of a preparator, located within a settling pond, has been substantiated. The research, concerning mineral disintegration, has helped identify that the average value of the maximum deflector radius, shaped as a result of counter jetting action, is $R_{\max }=0.3-0.5 \mathrm{~m}$; at the same time, the average value of the maximum radius of a hole, shaped resulting from helical jetting action around suction pipe, is $R_{\max }=0.3 \mathrm{~m}$.

Originality. For the first time, a mathematical model to use cumulation and deflation effects for a mineral disintegration has been developed as well as for preparation of filling material from mine tailing. The model reflects twists of helical $65-85^{\circ}$ jetting action with the maximum $0.5 \mathrm{~m}$ deflector radius and development of turbulence improving stope filling efficiency.

Practical value. The proposed procedure is the theoretical background to develop automated system of amber extraction from sandy and clay rocks, which will improve productive capacity of the mining process substantially.

Keywords: amber, placer, sandy and clay rock, extraction, cumulation, deflation

Introduction. The key problem, faced by mining industry, is to increase mineral extraction output while increasing the production using the most efficient underground and surface procedures based upon widespread implementation of the advanced technique as well as mining and conveyor facilities [1].

The current state of mineral mining in Rivne-Volyn region is characterized by the availability of numerous commercial amber deposits being extracted as well as those ones not involved in the process since their traditional operation is impossible due to the complicated mining and geological conditions [2]. Hence, conventional activities of the deposits are both ineffective and cost-intensive.

Geological features of amber deposits are the important factors denoting the main research tendency solving the problem of the mineral mining. Amber is fossilized resin of ancient conifers, which maintained its purity, clarity, and bright colour within coastal sandy deposits. Submarine placers as well as coastal-marine ones, occurring in the deposits from the Lower Cretaceous to Quarternary period are the basic types of amber deposits and fossil resin ones [3].

Klessiv amber deposit in Ukraine is connected with the Paleogene Period. Productive stratum of the deposit consists of three sand layers involving irregular course clay quartz, rich in sand matter, organic matter, and amber. Lower layer is rich sporadically in glauconite, owing to which the amber-bearing rock is of bluish tint. Amber pieces are up to $10 \mathrm{~cm}$. Amber content is 15 up to $310 \mathrm{~g} / \mathrm{m}^{3}$. Annual amber output within Klessiv deposit is not more than $140 \mathrm{~kg}$. During a short period,

(C) Moshynskyi V.S., Korniienko V.Ya., Malanchuk Ye.Z., Khrystyuk A. O., Lozynskyi V. H., Cabana E. C., 2021
Klessiv amber was recognized both by the national and world markets.

While designing new facilities or their advancing, it is quite important to apply practices of development and use of the available equipment [4]. Numerous designs are based upon popular engineering solutions, widespread unification of components and assembly units while taking them into consideration. Among other things, the research uses the following processes:

1. Converting, i.e. application of the available machine for another purpose. Along with the mineral extraction and its putting in a dump, the basic mining mechanism operates as a disintegrator of the broken rock. It applies cumulation and deflation effects in the mode of counter jets.

2. Use of the basic aggregate, i. e. development of standard uniform devices with average expedient parameters on the basis of one of the machine components. Mechanical and hydraulic testing aggregates as well as mechanical and hydraulic mining aggregates were used on the basis of the handle, and bucket of the base excavator depending upon washing out of a mineral. Thus, to mine sites of a deposit, consisting of easily washable minerals, functional activity of mechanical and hydraulic mining aggregate is to drive a stope, put the cut mineral in a dump, and then in the flooded stope. The aggregate cannot operate as the mineral disintegrator.

3. Compounding, i.e. parallel combination of the system components. For instance, one pump is quite sufficient for testing; it is insufficient for mining. For the purpose, one more pump is connected in parallel. In this context, water consumption duplicates. Parallel operation of two or more compressors is required while mining the deposit sites consisting of easily washable minerals. 
4. Modifying, i.e. the machine adapting to other service conditions. For instance, if amber is extracted from dumps and pillars, whose acceptable grades are substantiated as losses for open pit mining. Moreover, the proposed system may be applied to extract construction materials differing in their granulometric composition.

5. Aggregating, i. e. design of the machine of different purpose using one transport facility.

6. Developing of equipment series, i. e. design of facilities often needs single-purpose machines to be applied widely in terms of their basic parameters.

Testing and designing system is the organized structure of the controlled elements integrated by means of power, material, technological, and information connections pursuing such a shared objective as safety and efficiency.

Generally, primary mission is to divide a system into local purposes and elements, forming it, and determine their parameters.

It is possible to separate and systematize the following basic components of the studied object: opening; development of panels, blocks, and stopes; mechanical and hydraulic mining of a mineral; disintegration of the broken enclosing rock and the mineral in the flooded environment using hydromonitor jets; hydraulic rock failure in the flooded environment; pulp airlifting; rock pressure control; mineral preparation; stope filling; environmental protection; and working agent supply for the amber extraction facilities.

The procedure and its components have selected a working agent selection, i. e. water. It provides stream-lining and a small number of processes; remoteness of mining operations owing to high level of mechanization and automation; widespread use of labour- and power-saving gravity hydraulic transport; intensification of processes; and favourable combination of the working agent phases to intensify the mining technique. To achieve optimum operational modes of hydromining equipment, the elements, connected directly with stoping, should be balanced as for the working agent consumption.

Disbalance provokes such negative side effects as decrease in load capacity of pillars and strength degradation of stope roof rocks. Hence, consideration of hydromining system as the ordered structure of elements, and working agent as contact point of the elements having local goals and numerous optimality indices helps understand that the working agent balance is one of the criteria to evaluate the systems from the viewpoint of their profitability, intensity, and safety of amber extraction technique.

In the context of stoping and combination systems, along with its primary use, working agent fulfil reversing functions to decrease losses of a mineral within the Earth's interior. The reversing process is not singled out as a separate system element since it is of a local nature. Moreover, it is not a mandatory part of a technological process. Water saturation of a layer or broken-down mineral to make it move is an extra function of a working agent as well as integral condition to solve problems of mining efficiency. Working two-phase agents (i. e. water and heavy air) is expedient to be applied for the systems, used under the complicated mining and geological conditions. Heavy air is required for fissure opening to disintegrate a mineral. Combination systems with underground pillar extraction, using aqueous acid solutions to mine useful components from pillars, are the separate problem and its solutions.

Selection of a water agent as a link of the basic components of the system is of alternative nature; selection of its phases to implement extra components is of experimental nature.

It is usual to divide hydromonitor jets into low pressure jets (up to $1 \mathrm{MPa}$ ); medium pressure jets (up to $4 \mathrm{MPa}$ ); and high pressure jets (more than $4 \mathrm{MPa}$ ). Liquid motion within a jet is characterized by water particle transfer in terms of non-available solid channel boundaries. If motion of jets takes place, several liquids, differing in their density, intermix; if a jet mat- ter and medium matter are under different physical conditions or under multiphase conditions (i. e. gaseous state or a droplet one or sometimes with impurities of solid particles in the boundary layer of the jet), then such extremely phenomena originate that there are no reliable methods to determine them analytically.

Specificity of jet formation within a hydromonitor is as follows: in the process of water flow moving to a nozzle, it comes across various supports, which favour the flow tubulisation and cavitation deteriorating and derating the hydromonitor jet. Final jet formation takes place within the nozzle intended to transform static water pressure into kinetic energy of the jet. Moreover, decrease in the nozzle section increases water velocity due to its constant consumption. Simultaneously, nozzle loss of head happens being proportional to the jet velocity squared. Within the finite nozzle section, static pressure passes into impact pressure; no losses are available.

If a hydromonitor jet moves in the air at certain distance from the nozzle, then it almost disintegrates at the end of the initial section; hence, it may be characterized with the help of static description of individual components of the mobile water-air mixture. General form of hydromechanical equation for turbulence of discrete medium cannot be solved.

Hydromonitor jets may break-down any hard rock. However, the destruction with the help of a jet is mainly applied while mining low-viscosity and loose rocks (sand, loam, clay sandstone, aleurite, and so on). Rarely, half-rocks (coal, argillite, chalky clay, shale, limestone sandstone) are involved.

Physical-geological, hydraulic, and technological factors influence the intensity of hydraulic disintegration of rocks. Physical-geological factors include rock strength, hardness, composition, structure, texture, porosity, fissility, wettability, permeability, viscosity, brittleness and others. In total, they characterize rock washout (i. e. disintegration).

Hydraulic factors include hydraulic pressure, and water rate, i.e. characteristic of a hydromonitor jet. Conditions of jet influence on a stope (i.e. jet velocity relative to the stope), nozzle-stope distance, jet-stope incidence angle, mining procedure, the number of the exposed surfaces, and the stope orientation relative to fissility are technological factors.

Increase in porosity, fissility, soaking, and filtration coefficient results in washout acceleration; increase in hardness, plasticity, and adhesion coefficient decelerates it. At the same time, content of different fractions of mineral particles in rock as well as their adhesion also characterizes its hydraulic disintegration.

Complexity and insufficient information on the washout phenomenon involve the necessity to identify the required jet head as well as specific water consumption approximately; only experiments and operating conditions help specify them.

Unsolved aspects of the problem. Stope dimensions are subject to its mining period [5], physicomechanical characteristics of the mineral [6] and waste rocks [7], methods to support the mined-out area [8], as well as mining and geological conditions of the rock mass occurrence [9]. The parameters identify geometry of a preventer mounted in the neighbourhood of the stope collar.

In the process of deposit operation, one-size preventer with metal-intensive design may be applied. The abovementioned involves extra time consumption and cash outflow to transport it, assemble, and disassemble. It is more expedient to have several preventer designs for different operational conditions since two independent processes are separated technologically [10]. Process 1 is mineral cutting within the periphery of a stope. The procedure is performed by means of a working organ with simultaneous filling of the stope internal space with the broken-down mineral. Process 2 is the broken-down mineral disintegration within the closed environment of the flooded stope using cumulation and deflation effects.

Results. In terms of resistance of enclosing rocks as for disintegration, they are divided into easily, moderately, and prob- 
lematically washable ones. Washability degree is characterized by the washability index-plasticity ratio

$$
K_{p r}=\frac{p v_{1}}{v_{2} \omega},
$$

where $p$ is plasticity factor, $\%$; $v_{1}$ is sludge fraction yield $(<0.1 \mathrm{~mm}), \%$; $v_{2}$ is yield of $+8 \mathrm{~mm}$ size fraction, $\%$; $\omega$ is mineral humidity, $\%$.

Plasticity factor is characterized by the expression

$$
p=\omega_{b}-\omega_{H},
$$

where $\omega_{b}$ is humidity of clay fractions in terms of upper liquid limit, $\% ; \omega_{H}$ is humidity of clay fractions in terms of lower liquid limit, $\%$.

$K_{p r}<1$ for easily washable rocks; $K_{p r}=1-1.5$ for moderately washable rocks; and $K_{p r}>1.5$ for problematically washable ones [11].

The Table determines the washability category.

Generally, enclosing rock of amber placers of the region is considered as easily washable [12]. For the purpose, wet screening of samples with 20 cubic meters amount was performed in loose mass during two minutes. Test drum was applied with $1 \mathrm{~m}$ diameter; $0.2 \mathrm{~m}$ length; 3 and $15 \mathrm{~mm}$ diameters of perforation windows. Water consumption was equal to $0.7 \mathrm{l} / \mathrm{s}$ with $30 \mathrm{rpm}$ of the drum.

Specific feature of easily washable sandy and clay enclosing rock is that cyclogram of the deposit site mining additionally includes the following processes [13, 14].

Stage 1 is enclosing rock extraction from a stope and putting it in a dump right near a preventer. The process terminates when the stope bottom is located at the surface of enclosing rocks.

Stage 2 is to install a high-pressure armoured sleeve within the stope. Lower end of the sleeve is placed on the stope bottom in the form of a spiral; the sleeve end, equipped with a metal joint, is blanked off. The sleeve part, located right on the stope bottom, is equipped with the normally closed perforation windows. The normally closed perforation windows are considered as holes within the sleeve walls connected with internal cavity of the latter. If a working agent (i. e. water, air) is not available, then they are closed within the internal cavity of the sleeve owing to elastic properties of rubber being a construction material. Pressure feed of a working agent into internal sleeve cavity results in the following: the windows turned out to be open and the working agent can contact with the mined out area of the stope.

Stage 3 is recharge formation within the mined-out area of the stope at the expense of filling it with the broken-down rock mass from a dump while using the automated system of hydraulic mining. Then the filled stope is overflooded from a settling pond with the help of a pump motor assembly.

Stage 4 is just disintegration of the broken-down and recharged enclosing rock within the mined-out area of the stope using the two-phase working agent. A compressor plant supplies heavy air into the internal cavity of the armoured sleeve. Through the perforation windows, the heavy air is delivered to the body of the mineral recharge. They disperse the heavy air; in such a way, stoppage as well as rod-like liquid leaking is prevented. Penetrating porous space of a recharge, the heavy air

Table

\begin{tabular}{|c|c|c|}
\hline \multirow{2}{*}{$\begin{array}{l}\text { Washability } \\
\text { category }\end{array}$} & \multicolumn{2}{|c|}{ Fraction yield, $\%$} \\
\hline & $<0.2 \mathrm{~mm}$ & $<0.074 \mathrm{~mm}$ \\
\hline Easy & up to 0.5 & up to 3 \\
\hline Moderate & $5-15$ & $3-12$ \\
\hline Problematic & $>15$ & $>12$ \\
\hline
\end{tabular}

Washability categories of a mineral widens it. The abovementioned results in volumetric deformation of rocks, and their following disintegration. In addition, joint system is formed. The system reduces rock strength resulting in its disintegration.

Further, special attention will be paid to physical effects of cumulation and deflation, taking place under the conditions of turbulent flow since the theory of turbulence is quite complicated being not fully developed. Taking into consideration complex nature of a flow motion, one can identify important regularities of changes in its parameters.

Mining procedure of moderately washable rocks has been highlighted sufficiently in the foregoing. To evaluate kinetic parameters of counter flows (Fig. 1), assume that the total velocity of a liquid particle $V$ within point $M$ (Fig. 1) depends upon two components: axial velocity $V_{z}$ and rotational velocity $V_{n}$, i.e.

$$
V^{2}=V_{z}^{2}+V_{n}^{2}
$$

where $V_{z}=\frac{d z}{d t} ; V_{n}=r \cdot \frac{d \phi}{d t}, r$ is vortex radius.

Moreover, assume that velocity vector $V$ and vortex vector $\varepsilon$ coincide as for their direction while maintaining constant ratio as for the absolute value

$$
\frac{|\varepsilon|}{|V|}=\frac{K}{2}
$$

where $K$ is some dimensional constant, $M^{-1}$.

Suppose in the first approximation that flow rate is a constant. Then state of the liquid motion is described with the help of Gromek-Milovich equations

$$
\frac{d^{2} V_{z}}{d r^{2}}+\frac{1}{r} \frac{d V_{z}}{d r}+K^{2} V_{z}=0 ; \quad V_{n}=\frac{1}{K} \cdot \frac{d V_{z}}{d r}
$$

In this context, differential equation (2) is the Bessel equation.

If additional conditions are set when $V_{z}=V_{z_{0}} ; V_{n}=$ $=V_{n_{0}}\left(\left.\frac{d V_{z}}{d r}\right|_{r=r_{0}}=V_{n_{0}} \cdot k\right)$, then we obtain Cauchy problem for the Bessel problem.

To determine the flow velocities, let us do as follows. Let initial conditions (i.e. certain velocity values) be established for the system of differential equations (2)

$$
\begin{aligned}
& V_{z}=V_{z_{0}} ; \\
& V_{n}=V_{n_{0}} .
\end{aligned}
$$

Hence, we obtain

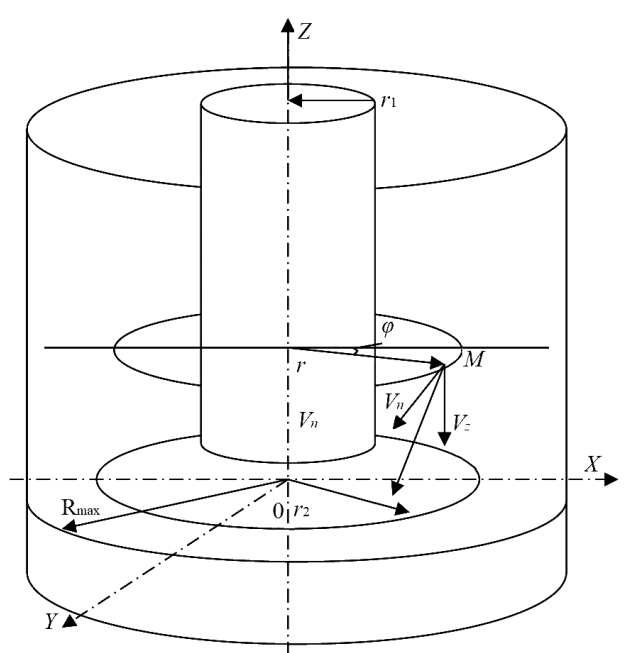

Fig. 1. Kinematic scheme to solve a problem with cumulation and deflation effects 


$$
V_{z}=C \cdot J_{0}(K \cdot r)+C_{1} \cdot Y_{0}(K \cdot r),
$$

where $C$ and $C_{1}$ are some (not defined) constants; and $J_{0}(K \cdot r)$, $Y_{0}(K \cdot r)$ are the Bessel functions of the $1^{s t}$ and $2^{\text {nd }}$ kinds of a zero order.

General solution (2) is as follows

$$
V_{n}=C \cdot J_{1}(K \cdot r)+C_{1} \cdot Y_{1}(K \cdot r),
$$

where $J_{1}(K \cdot r), Y_{1}(K \cdot r)$ are the first-order Bessel functions of the $1^{s t}$ and $2^{\text {nd }}$ kinds.

Taking into consideration (3) and (4), we have

$$
\begin{aligned}
& V_{z_{0}}=C \cdot J_{0}\left(K \cdot R_{b, T}\right)+C_{1} \cdot Y_{0}\left(K \cdot R_{b, T}\right) ; \\
& V_{n_{0}}=C \cdot J_{1}\left(K \cdot R_{b, T}\right)+C_{1} \cdot Y_{1}\left(K \cdot R_{b, T}\right) .
\end{aligned}
$$

The abovementioned makes it possible to determine values of $C$ and $C_{1}$ constants

$$
\begin{aligned}
& C=\frac{V_{z_{0}} \cdot Y_{1}\left(K \cdot R_{b, T}\right)-V_{n_{0}} \cdot Y_{0}\left(K \cdot R_{b, T}\right)}{J_{1}\left(K \cdot R_{b, T}\right) \cdot Y_{0}\left(K \cdot R_{b, T}\right)-J_{0}\left(K \cdot R_{b, T}\right) \cdot Y_{1}\left(K \cdot R_{b, T}\right)} ; \\
& C_{1}=\frac{V_{z_{0}} \cdot J_{1}\left(K \cdot R_{b, T}\right)-V_{n_{0}} \cdot J_{0}\left(K \cdot R_{b, T}\right)}{J_{1}\left(K \cdot R_{b, T}\right) \cdot Y_{0}\left(K \cdot R_{b, T}\right)-J_{0}\left(K \cdot R_{b, T}\right) \cdot Y_{1}\left(K \cdot R_{b, T}\right)} .
\end{aligned}
$$

Taking into consideration (6) and (7) we have

$$
\operatorname{tg} \phi=\frac{V_{n_{0}}}{V_{z_{0}}}=\frac{C \cdot J_{0}\left(K \cdot R_{b, T}\right)+C_{1} \cdot Y_{0}\left(K \cdot R_{b, T}\right)}{C \cdot J_{1}\left(K \cdot R_{b, T}\right)+C_{1} \cdot Y_{1}\left(K \cdot R_{b, T}\right)},
$$

where angle $\phi$ characterizes the flow intensity.

The last congruence helps derive the nonlinear equation to determine $K$

$$
\begin{gathered}
C \cdot\left[J_{0}\left(K \cdot R_{b, T}\right)-\operatorname{tg} \phi \cdot J_{0}\left(K \cdot R_{b, T}\right)\right]+ \\
+C_{1} \cdot\left[Y_{0}\left(K \cdot R_{b, T}\right)-\operatorname{tg} \phi \cdot Y_{0}\left(K \cdot R_{b, T}\right)\right]=0,
\end{gathered}
$$

or, taking into consideration (8), we obtain

$$
\begin{aligned}
& \quad\left[V_{z_{0}} \cdot Y_{1}\left(K \cdot R_{b, T}\right)-V_{n_{0}} \cdot Y_{0}\left(K \cdot R_{b, T}\right)\right] \times \\
& \quad \times\left[J_{0}\left(K \cdot R_{b, T}\right)-\operatorname{tg} \phi \cdot J_{1}\left(K \cdot R_{b, T}\right)\right]+ \\
& +\left[V_{z_{0}} \cdot J_{1}\left(K \cdot R_{b, T}\right)-V_{n_{0}} \cdot J_{0}\left(K \cdot R_{b, T}\right)\right] \times \\
& \times\left[J_{0}\left(K \cdot R_{b, T}\right)-\operatorname{tg} \phi \cdot Y_{1}\left(K \cdot R_{b, T}\right)\right]=0 .
\end{aligned}
$$

To perform engineering calculations using simpler and more comfortable equations, we simulate equal jet by means of a vortex line located along $O Z$ axis of cylindrical coordinate system.

Since the solution should be a bounded one (with $r=0$ ) from the physical viewpoint, we will seek it in the form of

$$
V_{z}=C \cdot J_{0}(K \cdot r) \text {. }
$$

Taking into consideration (9), we obtain

$$
C=\frac{V_{z_{0}}}{J_{0} \cdot\left(K \cdot R_{b, T}\right)} \text {. }
$$

Then we have

$$
\begin{aligned}
& V_{z}=\frac{V_{z_{0}}}{J_{0}\left(K \cdot R_{b, T}\right)} \cdot J_{0}(K \cdot r) ; \\
& V_{n}=\frac{V_{n_{0}}}{J_{0}\left(K \cdot R_{b, T}\right)} \cdot J_{1}(K \cdot r) .
\end{aligned}
$$

It follows from formulas (11) and (12) that the velocity graphs $V_{z}$ and $V_{n}$ are similar to the graphs of the Bessel functions $J_{0}\left(K_{r}\right), J_{1}\left(K_{r}\right)$ in accordance with certain constant coefficients

$$
K_{1}=\frac{V_{z_{0}}}{J_{0}\left(K \cdot R_{b, T}\right)}=\text { const; } \quad K_{2}=\frac{V_{n_{0}}}{J_{0}\left(K \cdot R_{b, T}\right)}=\text { const. }
$$

Involving (11) and (12), we define expression to derive $K$ coefficient

$$
\operatorname{tg} \phi=\frac{V_{n_{0}}}{V_{z_{0}}}=-\frac{J_{1}\left(K \cdot R_{b, T}\right)}{J_{0}\left(K \cdot R_{b, T}\right)} .
$$

Hence, we have nonlinear equation to determine $K$

$$
J_{1}\left(K \cdot R_{b, T}\right)+\operatorname{tg} \phi \cdot J_{0}\left(K \cdot R_{b, T}\right)=0 .
$$

While substituting $r=R_{\max }$ in (18) and (19) formulas, determine analytical values of axial $V_{z_{1}}$ and $V_{z_{2}}$ as well as rotational $V_{n_{1}}$ velocities within the helical-pulp interaction zone in a deflation hole

$$
\begin{aligned}
& V_{z_{1}}=V_{z_{0}} \cdot \frac{J_{0}\left(K \cdot R_{\max }\right)}{J_{0}\left(K \cdot R_{b, T}\right)} ; \\
& V_{n_{1}}=\frac{V_{n_{0}}}{\operatorname{tg} \phi} \cdot \frac{J_{1}\left(K \cdot R_{\max }\right)}{J_{0}\left(K \cdot R_{b, T}\right)} .
\end{aligned}
$$

Pulp consumption within the deflation zone is identified using the formula

$$
Q_{n}=\int_{0}^{2 \pi} \int_{R_{b, T}}^{R_{\max }} r \cdot V_{z} d \phi \cdot d r .
$$

Taking into consideration dependence (11), we obtain

$$
Q_{n}=\int_{0}^{2 \pi} \int_{R_{b, T}}^{R_{\max }} r \cdot\left[C \cdot J_{0}(K \cdot r)+C_{1} \cdot Y_{0}(K \cdot r)\right] d \phi \cdot d r=
$$$$
=\frac{2 \pi}{J_{0}\left(K \cdot R_{b, T}\right) \cdot Y_{1}\left(K \cdot R_{b, T}\right)-J_{1}\left(K \cdot R_{b, T}\right) \cdot Y_{0}\left(K \cdot R_{b, T}\right)} \times
$$$$
\times\left[\left(V_{z_{0}} Y_{1}\left(K \cdot R_{b, T}\right)-V_{n_{0}} Y_{0}\left(K \cdot R_{b, T}\right)\right) \int_{R_{b, T}}^{R_{\max }} r \cdot J_{0}(K \cdot r) d r+\right.
$$

$+\left(V_{n_{0}} \cdot J_{0}\left(K \cdot R_{b, T}\right)-V_{z_{0}} \cdot J_{1}\left(K \cdot R_{b, T}\right) \cdot \int_{R_{b, T}}^{R_{\max }} r \cdot Y_{0}(K \cdot r) d r\right]$.

After integration of (14), we determine

$$
\begin{gathered}
Q_{n}=\frac{2 \pi}{J_{0}\left(K \cdot R_{b, T}\right) \cdot Y_{1}\left(K \cdot R_{b, T}\right)-J_{1}\left(K \cdot R_{b, T}\right) \cdot Y_{0}\left(K \cdot R_{b, T}\right)} \times \\
\times\left[\left\{\left(V_{z_{0}} Y_{1}\left(K \cdot R_{b, T}\right)-V_{n_{0}} Y_{0}\left(K \cdot R_{b, T}\right)\right)\left[\Phi\left(R_{\max }\right)-\Phi\left(R_{b, T}\right)\right]+\right.\right. \\
+\left[\left(V_{n_{0}} \cdot Y_{0}\left(K \cdot R_{b, T}\right)-\left(V_{z_{0}} \cdot Y_{1}\left(K \cdot R_{b, T}\right)\right] \cdot\left[F\left(R_{\max }\right)-F\left(R_{b, T}\right)\right]\right\},\right.
\end{gathered}
$$

where

$$
\begin{gathered}
\Phi(r)=\sum_{i=0}^{\infty} \frac{(-1)^{i}}{(i !)^{2}} \cdot\left(\frac{K}{2}\right)^{2 i} \cdot \frac{r^{2 i+2}}{2 i+2} ; \\
F(r)=\int r, Y_{0}(K \cdot r) d r .
\end{gathered}
$$

For the simplified model of hydrodynamic disintegration process, based upon formula (11), we get

$$
Q_{n}=\frac{2 \pi \cdot V_{z_{0}}}{J_{0}\left(K \cdot R_{b, T}\right)} \cdot \int_{0}^{2 \pi} \int_{R_{b, T}}^{R_{\max }} r \cdot J_{0}(K \cdot r) d \phi \cdot d r .
$$

While applying representation of the Bessel function $J_{0}(K \cdot r)$, integration of (15) helps derive

$$
Q_{n}=\frac{2 \pi \cdot V_{z_{0}}}{J_{0}\left(K \cdot R_{b, T}\right)} \cdot\left[\Phi\left(R_{\max }\right)-\Phi\left(R_{b, T}\right)\right] .
$$

As (16) explains, consumption of the formed $Q_{n}$ pulp depends linearly upon $V_{z 0}$ velocity.

The mathematical analysis of mineral disintegration has helped develop the integrated programme to calculate and represent the obtained results with the help of computer graph 
means with visualization of the simulated hydrodynamic disintegration of the broken-down mineral within the closed space. The abovementioned makes it possible to analyse numerically the obtained results for different input data and study the disintegration process thoroughly.

Analysis of the data from scientific sources [15] as well as the calculation experiments [16] helped determine that $\phi$ angle, characterizing a helical flow swirling, varies within $65^{\circ} \leq$ $\leq \phi \leq 85^{\circ}$.

Findings of the research as for the mineral disintegration helped understand that average value of the maximum deflector radius, shaped as a result of counter jetting, is $R_{\max }=0.3-$ $0.5 \mathrm{~m}$.

While applying such numerical experimental values as $R_{b, T}=0.006 \mathrm{~m}, R_{\max }=0.3 \mathrm{~m}$, and $V_{z 0}=0.45 \mathrm{~m} / \mathrm{s}$, we determine $Q_{n}=4.9 \cdot 10^{-2} \mathrm{~m}^{3} / \mathrm{s}$.

Below we consider the amber deposit mining procedure involving stope filling by means of the broken-down rock. A technique to fill hydraulically the mined-out stope area is applied. The method is based upon water energy use to transport and stow filling materials. The filling material is stowed with the help of its own gravity.

Filling material should have high transportability along with minimum water consumption, return water easily, contain certain share of clay particles (no more than $15 \%$ ), and feature low cost [17]. Lower size boundary of definite grains of the filling material depends upon water transportation of small fractions from the mined-out stope area; upper boundary depends upon a condition of normal pulp transportation through pipelines and development of reliable filling mass [18]. Pulp mobility is subject to its consistence $(S: L)$; filling material density; particle size and shape; and a pipeline geometry [19].

The following formula determines the optimal solid fraction-liquid ratio

$$
S: L=\frac{2 L_{s}}{2 A_{s}+L_{s}},
$$

where $L_{s}$ is the ratio between the total length of vertical sections and the total length of horizontal sections of a pulp feedline inclusive of the total pipeline length being equal to local supports; $A_{s}$ is the average coefficient of pulp motion resistance.

If maximum grain size of filling material is $1-2 \mathrm{~mm}$ then $S: L=1: 1-1: 2$ is the ideal composition consistency.

Generally, compaction of the filling material within the mined-out stope area takes place under proper pressure. The process is characterized by the filling coefficient (on a percentage base)

$$
K_{y}=100 \frac{U_{o}-U_{k}}{U_{o}},
$$

where $U_{o}$ is the amount of the filling mass at the moment of its erection (it corresponds to the amount of the worked-out stope area); $U_{k}$ is amount of the filling mass after certain time interval.

After the filling material is compacted, some share of the mined-out area is filled up with pulp. Then, the cycles to fill the mined-out area are restarted. Close water distribution system (CWDS) of mechanical and hydraulic mining system is used as filling facilities for pulp transportation [20]. In this context, a sucker of a soil pump operates according to the tracking system on the bottom of a sediment pond to achieve the most favourable consistency of pulp delivered to the mined-out stope area.

The filtration coefficient characterizes a rate of water return by the filling mass

$$
K_{f}=\frac{Q_{f}}{J \cdot S},
$$

where $Q_{f}$ is return of the filtered water; $S$ is a cross area through which water is filtered; $J$ is hydraulic gradient.
In this case, for amber placers it is as follows

$$
S=L_{p r}^{2}+4 L_{p r} m ; \quad J=\frac{H_{i}-H_{h}}{m},
$$

where $H_{i}$ is pressure within a stope collar being equal to the atmospheric one; $H_{h}$ is pressure on the stope bottom; $L_{p r}$ and $m$ are length and thickness of the deposit site.

Industrial site of mechanical and hydraulic amber mining in Rivne Region used pulp from a sediment pond as filling material. The pulp was delivered periodically to the mined-out stope areas. The analysis of the actual data helped identify average solid-liquid ratio in pulp being equal to $1: 1-1: 2$.

Consider physico-mathematical simulation of pulp taking from a sediment pond with the help of a soil pump. Since tailings densify with time, it is required to loosen them. For the purpose, we designed parametric series of loosening devices including empty housing and hydromonitor nozzles located tangentially on the inside of the housing. The housing is mounted on the lower edge share of a suction pipeline of a soil pump. A pipe connects the central hole of the housing with the major pipeline. There is a locking bar set on the pipe. If the soil pump operates in a water supply mode, then the locking bar is closed. If the soil pump operates in a mode of filling material delivery to the mined-out stope area, then the locking bar is open. Under hydraulic pressure, developed by the soil pump, water from a sediment pond is piped into the internal cavity of housing; the hydromonitor nozzles shape the water into jets to disintegrate tailings.

The disintegrated tailings are solid pump components; they are delivered to stopes with the help of a soil pump. The pipelines are made of flexible high-pressure sleeves which can move both horizontally and vertically. Simulation of sediment disintegration in tailings as well as pulp formation is similar to the algorithm described above.

If $r=r_{2}$, then the initial conditions should be set for differential equation system (2)

$$
\begin{gathered}
V_{z}=V_{z_{0}} ; \quad V_{n}=V_{n_{0}} \quad \text { if } r=r_{2} ; \\
V_{z} \leq V_{0}<\infty \quad \text { if } r=0 .
\end{gathered}
$$

General solution of (2) is similar to (5)

$$
V_{z}=C \cdot J_{0}(K \cdot r)+C_{1} \cdot Y_{0}(K \cdot r) .
$$

Let us simulate a suction pipe with the help of a vortex line located along $O Z$ axis of the cylindrical coordinate system. Since the solution should be a bounded one from the physical viewpoint (if $r=0$ ), we will seek in the form of (9); moreover, we will determine expression for $K$ coefficient

$$
\operatorname{tg} \phi=\frac{V_{n_{0}}}{V_{z_{0}}}=-\frac{J_{1}\left(K \cdot r_{2}\right)}{J_{0}\left(K \cdot r_{2}\right)} .
$$

From which we derive nonlinear equation for constant $K$

$$
J_{1}\left(K \cdot r_{2}\right)+\operatorname{tg} \alpha \cdot J_{0}\left(K \cdot r_{2}\right)=0,
$$

where $\phi$ is the angle characterizing intensity of a jet swirling.

The analysis of formulas (11) and (17) helps understand that graphs of $V_{z}$ and $V_{n}$ velocities are similar homothetically to such Bessel functions as $J_{0}(k r), J_{1}(k r)$ in accordance with certain constant tension coefficients

$$
K_{1}=\frac{V_{z_{0}}}{J_{0}\left(K \cdot r_{2}\right)} ; \quad K_{2}=\frac{V_{n_{0}}}{J_{0}\left(K \cdot r_{2}\right)} .
$$

In addition, the formulas represent velocity pulsations being of decaying nature along with $r$ increase. While substituting $r=R_{\max }$, we identify analytical values of axial velocity $V_{z}$ as well as rotational velocity $V_{n}$ within a washout hole where helical jet interacts with the pulp

$$
V_{z}=V_{z_{0}} \frac{J_{0}\left(K \cdot R_{\max }\right)}{J_{0}\left(K \cdot r_{2}\right)}
$$




$$
V_{n}=\frac{V_{n_{0}}}{\operatorname{tg} \phi} \cdot \frac{J_{1} \cdot\left(K \cdot R_{\max }\right)}{J_{0} \cdot\left(K \cdot r_{2}\right)} .
$$

According to (1), the total velocity value (based upon (11) and (12) is calculated using the formula

$$
V=\frac{1}{J_{0}\left(K r_{2}\right)} \cdot \sqrt{V_{z_{0}}^{2} \cdot J_{0}^{2}(K r)+V_{n_{0}}^{2} \cdot J_{1}^{2}(K r)}
$$

Consequently, a velocity value within the helical jet axis (if $r=0)$ is $V(0)=\frac{1}{J_{0}\left(K r_{2}\right)} \cdot \sqrt{V_{z_{0}}^{2} \cdot J_{0}^{2}(0)+V_{n_{0}}^{2} \cdot J_{1}^{2}(0)}$.

Since $J_{0}(0)=1, J_{1}(0)=0$, then we have from the last formula

$$
V(0)=\frac{V_{z_{0}}}{J_{0}\left(K r_{2}\right)}
$$

Pulp consumption within the washout hole is defined with the help of formula (13). Taking into consideration (11) dependence, we have

$$
Q_{n}=\frac{2 \pi \cdot V_{z_{0}}}{J_{0}(0)} \cdot \int_{0}^{2 \pi} \int_{0}^{R_{\max }} r \cdot J_{0}(K \cdot r) d \phi \cdot d r .
$$

While applying representation of the Bessel function $J_{0}(K \cdot r)$ and involving the fact that $J_{0}(0)=1$, we obtain after (17) integration

$$
Q_{n}=2 \pi V_{z_{0}} \cdot \Phi\left(R_{\max }\right) ; \quad \Phi(r)=\sum_{i=0}^{\infty} \frac{(-1)^{i}}{(i !)^{2}} \cdot\left(\frac{K}{2}\right)^{2 i} \cdot \frac{r^{2 i+2}}{2 i+2} .
$$

The area within the sucking zone, being free of soil and vortex, is filled with water flows. To make the process of soil suction continuous, a value of hole depth $h$ should not excess certain critical value $h \leq h_{k}$ which depends upon the soil nature, suction velocity within the pipe mouth, geometry of the pipe, and its dimensions. The dependence may be helpful to determine depth of the suction hole $h$

$$
h=r_{1} \cdot \sqrt{\frac{V_{b c}}{2 V_{p}}},
$$

where $V_{b c}$ is the average suction velocity within the pipe mouth; $V_{p}$ is the washout velocity for the soil type.

Maximum radius of suction holes is

$$
R_{\max }=3 h .
$$

Vacuum head is determined on the formula

$$
H_{v a k}=H_{r} \cdot \frac{\gamma_{n}}{\gamma_{b}}+H_{p}\left(1-\frac{\gamma_{b}}{\gamma_{n}}\right)+h_{b x}+h_{b c}+\frac{\vartheta_{*}}{2 g},
$$

where $H_{r}$ is geodetic suction head; $H_{p}$ is mining depth; $\gamma_{b}$ and $\gamma_{n}$ are water density and pulp density; $h_{b x}$ is hydraulic loss at the entry of the suction pipe; $h_{b c}$ is hydraulic loss within the suction pipe; $\frac{\vartheta_{*}}{2 g}$ is dynamic velocity pressure at the entry of the soil pump; $\vartheta_{*}$ is the pulp velocity at the entry of the soil pump.

Efficiency of the suction head with free suction can be identified using the formula

$$
W_{p}=3600 \cdot C \cdot \omega_{b c} \cdot V_{b c},
$$

where $C$ is volume pulp consistency; $\omega_{b c}$ is a suction hole area; $V_{b c}$ is the suction velocity.

Based upon software implementation of the abovementioned problem, calculation experiments were performed which made it possible to analyse the obtained results for different input data of washout and pulp suction (Fig. 2). It was determined that average value of the maximum hole radius, shaped as a result of helical jet action around suction pipe, is $R_{\text {max }}=0.3 \mathrm{~m}$.

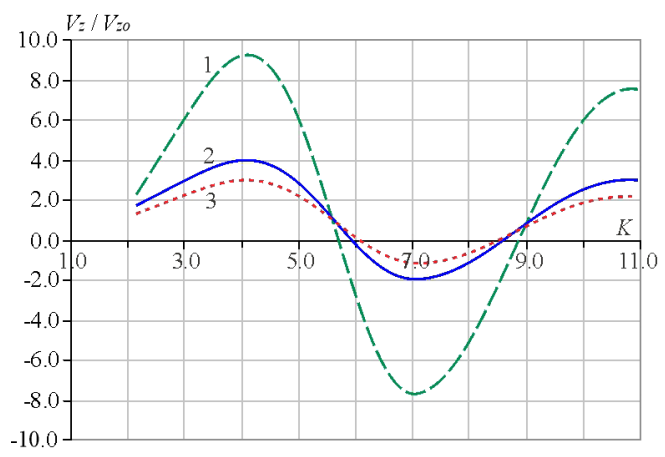

$a$

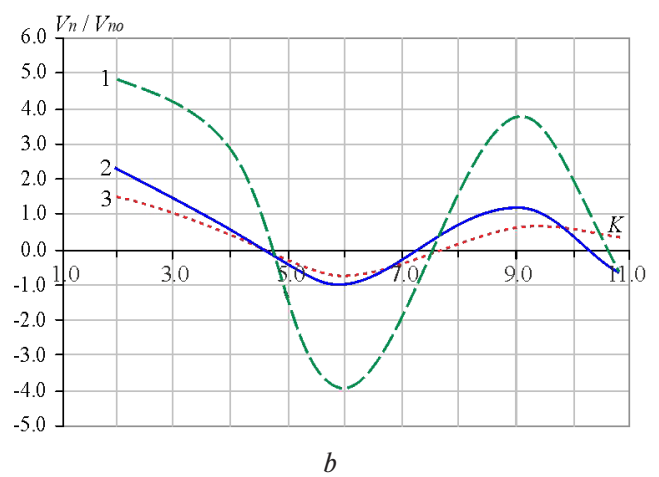

Fig. 2. Graphs of changes in relative velocities of helical jet in terms of dimensionless coordinate $(K)$ depending upon pulp consumption $Q_{n}$ :

1, 2 and 3 are 100, 50, and $25 \mathrm{~m}^{3} /$ hour respectively: a - graph of change in axial velocity; $b$ - graph of change in helical velocity

As a result of the obtained data visualization, Fig. 2 demonstrates graphs of changes in relative velocities of helical jet $V_{z} / V_{z 0}$ and $V_{n} / V_{n_{0}}$ if $R_{b, T} \leq r \leq \bar{R}_{\max }$. Their analysis shows that change in $2 \leq K \leq 10$ factors into the co-phased variation of axial $V_{z}$ and rotational $V_{n}$ velocities of helical jet in accordance with $J_{0}\left(K_{r}\right)$, and $J_{1}\left(K_{r}\right)$ Bessel functions denoting the jet turbulence. In turn, the abovementioned supports intensification of washout processes, pulp formation, and channelization of the pulp flow towards the suction pipe axis with its following intake and elevation.

Conclusions. The research has improved a model of the amber mining procedure. In terms of amber placer prospecting, it is an alternative to its surface mining as for the economic indices and environmental requirements put forward the outcomes of amber placer operation in Ukraine. Method of sandy and clay rock mining $\left(K_{n p}<1\right)$ is characterized by the fact that the broken-down and recharged mineral within the mined- out stope area is disintegrated by means of heavy air delivery to the neighbourhood of the stope bottom. Airlifting is applied to transport pulp to the Earth's surface; in this context, stope walls are the 'mining pipe'.

A procedure of sandy and clay enclosing rock mining $\left(K_{n p}=\right.$ $1-1.5)$ is characterized by the broken-down mineral disintegration within the closed space (i.e. within a working organ of the extraction machine) in the water environment using mathematically modelled cumulation and deflation effects.

The methods and technology of filling material production from the preparation plant tailings, located in a sediment pond, have been simulated mathematically as a process of hydromonitor jet loosening. The jets operate in housing tangentially with the development of swirling pulp flows.

A mathematical model has been developed to apply cumulation and deflation effects for mineral disintegration as well as for production of filling materials from tailings. The model reflects $65-85^{\circ}$ helical jet swirling and $0.5 \mathrm{~m}$ maximum deflector radius with turbulence development to improve the efficiency of stope filling. 
The proposed procedure may become the theoretical basis to develop the automated system for amber extraction from sandy and clay enclosing rocks, which will improve significantly the mining process efficiency.

\section{References.}

1. Dychkovskyi, R., Vladyko, O., Maltsev, D., \& Cabana, E. C. (2018). Some aspects of the compatibility of mineral mining technologies. Rudarsko-Geološko-Naftni Zbornik, 33(4), 73-82. https://doi. org/10.17794/rgn.2018.4.7.

2. Perkovsky, E.E. (2017). Rovno Amber Caddisflies (Insecta, Trichoptera) from Different Localities, with Information about three New Sites. Vestnik Zoologii, 51(1), 15-22. https://doi.org/10.1515/ vzoo-2017-0003.

3. Malanchuk, Z., Moshynskyi, V., Malanchuk, Y., \& Korniienko, V. (2018). Physico-Mechanical and Chemical Characteristics of Amber. Solid State Phenomena, (277), 80-89. https://doi.org/10.4028/www. scientific.net/ssp.277.80.

4. Yussupov, Kh., Aben, Ye., Omirgali, A., \& Rakhmanberdiyev, A. (2021). Analyzing a denitration process in the context of underground well uranium leaching. Mining of Mineral Deposits, 15(1), 127-133. https://doi.org/10.33271/mining 15.01.127.

5. Begalinov, A., Khomiakov, V., Serdaliyev, Y., Iskakov, Y., \& Zhanbolatov, A. (2020). Formulation of methods reducing landslide phenomena and the collapse of career slopes during open-pit mining. E3S Web of Conferences, 168,00006.https://doi.org/10.1051/e3sconf/202016800006. 6. Shustov, O., Pavlychenko, A., Bondarenko, A., Bielov, O., Borysovska, O., \& Abdiev, A. (2021). Substantiation into Parameters of Carbon Fuel Production Technology from Brown Coal. Materials Science Forum, (1045), 90-101. https://doi.org/10.4028/www.scientific. net/MSF.1045.90.

7. Zhanakova, R., Pankratenko, A., Almenov, T., \& Bektur, B. (2020). Rational selection of the form of support for the formation of genetic composition of rocks in the conditions of the beskempir field. News of the National Academy of Sciences of the Republic of Kazakhstan, (439), 106-113.

8. Begalinov, A., Almenov, T., Zhanakova, R., \& Bektur, B. (2020). Analysis of the stress deformed state of rocks around the haulage roadway of the Beskempir field (Kazakhstan). Mining of Mineral Deposits, 14(3), 28-36. https://doi.org/10.33271/mining14.03.028.

9. Petlovanyi, M., Lozynskyi, V., Zubko, S., Saik, P., \& Sai, K. (2019). The influence of geology and ore deposit occurrence conditions on dilution indicators of extracted reserves. Rudarsko Geolosko Naftni Zbornik, 34(1), 83-91. https://doi.org/10.17794/rgn.2019.1.8.

10. Telkov, S. A., Motovilov, I.Y., Barmenshinova, M. B., Medyanik, N. L., \& Daruesh, G. S. (2019). Substantiation of Gravity Concentration to the Shalkiya Deposit Lead-Zinc Ore. Journal of Mining Science, 55(3), 430-436. https://doi.org/10.1134/s1062739119035769. 11. Malanchuk, Z., Moshynskyi, V., Malanchuk, V., Korniienko, Y., \& Koziar, M. (2020). Results of Research into the Content of Rare Earth Materials in Man-Made Phosphogypsum Deposits. Key Engineering Materials, (844), 77-87. https://doi.org/10.4028/www.scientific.net/kem.844.77.

12. Yulusov, S., Surkova, T.Y., Amanzholova, L. U., \& Barmenshinova, M. B. (2018). On sorption of the rare-earth elements. Journal of Chemical Technology and Metallurgy, 53(1), 79-82.

13. Moshynskyi, V., Malanchuk, Z., Tsymbaliuk, V., Malanchuk, L., Zhomyruk, R., \& Vasylchuk, O. (2020). Research into the process of storage and recycling technogenic phosphogypsum placers. Mining of Mineral Deposits, 14(2), 95-102. https://doi.org/10.33271/mining14.02.095.

14. Begalinov, A., Shautenov, M., Almenov, T., Bektur, B., \& Zhanakova, R. (2019). Prospects for the effective use of reagents based on sulfur compounds in the technology of extracting gold from resistant types of gold ore. Journal of Advanced Research in Dynamical and Control Systems, 11(8), 1791-1796.

15. Aben, E. K., Rustemov, S.T., Bakhmagambetova, G. B., \& Akhmetkhanov, D. (2019). Enhancement of metal recovery by activation of leaching solution. Mining Informational and Analytical Bulletin, (12), 169-179. https://doi.org/10.25018/0236-1493-2019-12-0-169-179. 16. Naduty, V., Malanchuk, Z., Malanchuk, Y., \& Korniyenko, V. (2016). Research results proving the dependence of the copper concentrate amount recovered from basalt raw material on the electric separator field intensity. Eastern-European Journal of Enterprise Technologies, 5(5(83)), 19-24. https://doi.org/10.15587/1729-4061.2016.79524. 17. Bitimbaev, M.Z., Krupnik, L.A., Aben, E. K., \& Aben, K. K. (2017). Adjustment of backfill composition for mineral mining under open pit bottom. Gornyi Zhurnal, (2), 57-61. https://doi.org/10.17580/ gzh.2017.02.10.

18. Motovilov, I.Y., Telkov, S.A., Barmenshinova, M.B., \& Nurmanova, A. N. (2019). Examination of the preliminary gravity dressing influence on the Shalkiya deposit complex ore. Non-Ferrous Metals, 47(2), 3-8. https://doi.org/10.17580/nfm.2019.02.01.

19. Arslanov, M.Z., Mustafin, S.A., Zeinullin, A.A., Kulpeshov, B. S., \& Mustafin, T. S. (2020). Model for determining classification of filling materials hardening. News of National Academy of Sciences of the Republic of Kazakhstan, 5(443), 6-12. https://doi. org/10.32014/2020.2518-170x.98.

20. Mustakhimov, A., \& Zeynullin, A. (2020). Scaled-up laboratory research into dry magnetic separation of the Zhezdinsky concentrating mill tailings in Kazakhstan. Mining of Mineral Deposits, 14(3), 7177. https://doi.org/10.33271/mining14.03.071.

\section{Моделювання процесів видобутку бурштину 3 пісчано-глинистих порід із закладкою виймальних камер}

\section{В. С. Мошинський , В.Я. Корнієнко ${ }^{1}$, С. З. Маланчук ${ }^{1}$, А. О. Христюк ${ }^{1}$ В. Г. Лозинський ${ }^{2}$, Е. К. Кабана}

1 - Національний університет водного господарства i природокористування, м. Рівне, Україна

2 - Геологічний концерн «Геобіт», м. Хжанув, Республіка Польща, e-mail: lvg.nmu@gmail.com

3 - Університет Святого Августина, м. Арекіпа, Перу

Мета. Розробити математичну модель системи видобутку бурштину на основі впливу фізичних ефектів кумуляції та дефляції в умовах турбулентних потоків.

Методика. При здійсненні теоретичного моделювання процесів видобутку враховувалися процеси конвертування, використання базового агрегату, компаундування, модифікування, агрегування та створення рядів обертання з урахуванням досвіду створення та експлуатації вже наявного аналогічного обладнання, конструктивних рішень широкої уніфікації деталей і складальних одиниць. Аналізуючи набутий теоретичний і практичний досвід, здійснювалося моделювання процесів видобутку бурштину з пісчано-глинистих порід із закладкою виймальних камер.

Результати. Математично змодельовано процес рихлення гірської маси гідромоніторними струменями, що діють в кожусі тангенціально із створенням закручених потоків пульпи. Обгрунтована технологія приготування закладного матеріалу із хвостів за допомогою збагачувальної установки, що розміщується у ставку-відстійнику. За результатами проведених досліджень по дезінтеграції корисної копалини, встановлено, що середнє значення максимального радіуса дефлектора, який утворюється внаслідок розмивної дії зустрічних струменів, становить $R_{\max }=0,3-0,5$ м, тоді як середнє значення максимального радіуса ями, що утворюється внаслідок розмивної дії гвинтового потоку навколо всмоктуючої труби, становить $R_{\max }=0,3$ м.

Наукова новизна. Уперше створена математична модель використання ефектів кумуляції та дефляції для дезінтеграції корисної копалини, а також приготування закладного матеріалу із хвостів збагачення, яка відображає крутки гвинтового потоку в межах 65-85 і максимальним радіусом дефлектора 0,5 м зі створенням турбулентності, що підвищує продуктивність закладання камер.

Практична значимість. Запропонована технологія $\epsilon$ теоретичною основою для розробки автоматизованої системи видобутку бурштину з пісчано-глинистих порід, що значно підвищить ефективність процесу розробки.

Ключові слова: бурштин, розсип, пісчано-глиниста порода, видобуток, кумуляція, дефляція

The manuscript was submitted 01.03.21. 